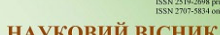

rater

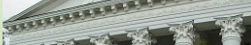

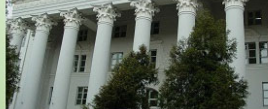

СЕРЯ "СЛЬСБКОГОСПОДАРСКК НАУК

Том 23 № 95

2021
Науковий вісник Яьвівського національного університету ветеринарної медицини та біотехнодогій імені С.3. Гжицького. Серія: Сільськогосподарські науки

\section{Scientific Messenger of Lviv National University} of Veterinary Medicine and Biotechnologies. Series: Agricultural sciences

UDC 636.2.083.3:631.22.018:631.86

\title{
The influence of the method of manure removal and storage on the quality of organic products
}

O. O. Borshch, O. V. Borshch, M. M. Fedorchenko

Bila Tserkva National Agrarian University, Bila Tserkva, Ukraine

Article info

Received 03.05.2021

Received in revised form 09.06.2021

Accepted 10.06.2021

Bila Tserkva National Agrarian University, pl. 8/1 Soborna, 09117, Bila Tserkva, Ukraine.

Tel.: +38-099-477-09-82

E-mail:borshcha@outlook.com
Borshch, O. O., Borshch, O. V., \& Fedorchenko, M. M. (2021). The influence of the method of manure removal and storage on the quality of organic products. Scientific Messenger of Lviv National University of Veterinary Medicine and Biotechnologies. Series: Agricultural sciences, 23(95), 65-70. doi: 10.32718/nvlvet-a9509

The aim of this article was to compare the quality of manure in different ways of its removal and storage for environmental pollution. The research was conducted in three farms of Kyiv region with different methods of manure removal, storage and processing: using deep long-lasting straw litter (manure removal three times a year); with manure processing in a closed bioreactor-fermenter of the closed type; with manure settling in open lagoons. In all farms, the average annual livestock is 400 dairy cows. Samples for analysis of manure (processing waste) were taken the day before export to the field. The average daily air temperature during sampling was $+21.3{ }^{\circ} \mathrm{C}$. In terms of the sum of nitrogen, phosphorus and potassium content in $1 \mathrm{~kg}$ of fertilizers, the highest indicators were observed for the variant of keeping in deep litter $7.69 \mathrm{~g}$. intermediate bioreactors-fermenters observed intermediate values - $6.69 \mathrm{~g}$. The highest moisture content of manure was during storage in the lagoon - by $19.71 \%$ and $1.38 \%$ more compared to the option on deep litter and in the bioreactor-fermenter. The lowest number of weed seeds was for storage in deep litter-84 pcs $/ \mathrm{ml}$, which is 19 and $23 \mathrm{pcs} / \mathrm{ml}$ more than for processing in a bioreactor-fermenter and storage in the lagoon. The indicator of weed germination, which is very important from the point of view of future use of manure as an organic fertilizer in general, had positive indicators for all storage (processing) options. The germination rate of weeds for storage in deep litter was $5.72 \%$, which is 3.14 and $4.42 \%$ less than for processing in a bioreactor-fermenter and in the lagoon. The largest emissions of $\mathrm{N}_{2} \mathrm{O}$ (nitric oxide) were in the variant of manure storage in the lagoon $-40712.45 \mathrm{~kg}$, which is $39781.88 \mathrm{~kg}$ more than in the options of storage in deep litter and in the bioreactor-fermenter. The content of nitrogen, phosphorus, potassium and organic matter of fertilizer obtained from $1 \mathrm{~kg}$ of manure from deep litter, exceeded similar indicators of other methods of storage due to daily application of straw.

Key words: dairy cows, deep litter, bioreactor-fermenter, open lagoon, organic fertilizer.

\section{Вплив способу видалення і зберігання гною на якість органічної продукції}

\author{
О. О. Борщ, О. В. Борщ, М. М. Федорченко
}

Білочерківський національний аграрний університет, м. Біла Церква, Украӥна

\footnotetext{
Метою иієї роботи було порівняння впливу складу гною за різних способів його видалення та зберігання на забруднення довкілля. Дослідження проводили у трьох господарствах Київської області з різними способами видалення, зберігання та переробки гною: з використанням глибокої довгонезмінюваної солом'яної підстилки (видалення гною тричі на рік); з переробкою гною в біореакторі-ферментері закритого типу; з відстоюванням гною у лагунах відкритого типу. У всіх господарствах середньорічне поголів'я становить 400 дійних корів. Проби для аналізу гною (відходів переробки) відбирали за добу до вивезення в поле. Середня добова температура повітря при відборі проб становила $+21,3{ }^{\circ} \mathrm{C}$. За сумою вмісту Азоту, Фосфору та Калію у 1 кг добрив найвищі показники спостерігали за варіанту утримання на глибокій підстилці - 7,69 г. Найменше иих елементів було у добриві, отриманому в результаті зберігання у лагуні - 6,16 г. За варіанту переробки гною у біореакторі-ферментері спостерігали проміжні показники - 6,69 г. Найвищий показник вологості гною був за зберігання в лагуні-95,25\%, що на 19,71 \% та 1,38\% більще порів-
} 
няно з варіантом накопичення і зберігання у приміщенні (глибока підстилка) та в біореакторі-ферментері. Найменша кількість насіння бур'янів була за зберігання на глибокій підстилці-84 шт/мл, щчо на 19 та 23 шт/мл менше, ніж за переробки у біореакторіферментері та зберігання у лагуні. Показник схожості бур'янів, котрий є дуже важливим з точки зору майбутнього використання гною як органічного добрива, загалом за всіх варіантів зберігання (переробки) мав неоднозначні показники. Показник схожості бур'янів за зберігання на глибокій підстилџі становив 5,72\%, щзо на 3,14 та 4,42 \% менше, ніж за переробки у біореакторіферментері та в лагуні. Найбільші викиди $\mathrm{N}_{2} \mathrm{O}$ (оксид азоту), були за варіанту зберігання гною в лагуні - 40712,45 кг, ияо на 39781,88 кг більше, ніж за варіантів зберігання на глибокій підстилці та у біореакторі-ферментері. Вміст Азоту, Фосфору, Калію та органічної речовини добрива, отриманого з 1 кг гною із глибокої підстилки, переважав аналогічні показники інших способів зберігання за рахунок щзоденного внесення соломи.

Ключові слова: молочні корови, глибока підстилка, біореактор-ферментер, лагуна відкритого типу, органічне добриво.

\section{Вступ}

Застосування органічних добрив $є$ одним 3 найбільш могутніх і швидкодіючих факторів підвищення родючості грунтів та врожайності всіх сільськогосподарських культур (Hoffman et al., 2007; Stowe et al., 2015; Hanson et al., 2016). Поліпшуючи умови живлення рослин за допомогою добрив, можна посилити ріст рослин, прискорити темпи їхнього розвитку і набагато збільшити урожайність. Крім цього, органічні добрива значно впливають на якість врожаю, збільшуючи в ньому кількість білка, цукру, крохмалю тощо, підвищують стійкість рослин проти несприятливих зовнішніх умов, захворювань $і$ дають можливість отримати екологічно чисту сировину й продукцію (Amon et al., 2007; Wang et al., 2012; Tien et al., 2017).

Сумарний ефект від внесення тонни гною становить у перерахунку на зерно 1,2 ц/га додаткової продукції. У зв'язку з цим здійснення заходів щодо збільшення нагромаджень органічних добрив повинно бути одним з головних завдань тваринницьких ферм в сучасних умовах господарювання. На молочних фермах великої рогатої худоби виробництво гною часто $\epsilon$ другою після виробництва молока продукцією (Coats et al., 2011; Zhong et al., 2012; Barret et al., 2013). Кожна особина великої рогатої худоби може дати не менше ніж 9 т гною на рік. Щоб одержати високоякісне органічне добриво, гній необхідно відповідним чином зберігати: у спеціальних гноєсховищах, ущільнених буртах на полі, в лагунах (Borshch et al., 2017). Оптимальна тривалість зберігання гною ВРХ не має перевищувати 4-5 місяців, а гній повинен набути напівперепрілого стану (Ruban et al., 2017; Borshch et al., 2020b; Ruban et al., 2020).

Упродовж останніх десятиліть на молочних фермах використовують системи переробки гною на біогаз, компост та способи зберігання у відстійниках, лагунах закритого та відкритого типу (Cao \& Harris, 2010). Як показує практика на багатьох фермах з виробництва молока, найбільша увага приділяється своєчасному видаленню гною для забезпечення нормального мікроклімату і чистоти приміщень, а питання екології та виробництва гною як добрива ігноруються. Водночас система внесення підстилки і видалення гною на молочних фермах та комплексах повинна забезпечувати оптимальні умови утримання тварин, дотримання доброго санітарного стану в приміщеннях, раціональне використання гною як органічного добрива, охорону довкілля від забруднення i бути малозатратною (Walsh et al., 2012; Toumi et al., 2015).

Найбільшою мірою цим вимогам відповідає безприв'язне утримання корів і ремонтних телиць на глибокій довгонезмінюваній солом'яній підстилці. За такого способу утримання тварини виділяють екскременти на підлогу приміщення - практично прямо у гноєсховище. Робочі процеси полягають у видаленні і вивезенні гною один або два рази на рік. Однак при цьому потрібні великі витрати соломи злакових культур, в 1 т якої міститься 5 кг азоту, 2,5 кг фосфору та 6 кг калію (Janzen et al., 1999; Resende et al., 2014).

Середньорічний вихід напівпрілого гною з глибокої підстилки становить 4-6 т у розрахунку на 1 корову. До складу гною входить 25-35 \% соломи і 65$75 \%$ екскрементів. До періоду прибирання цей гній стає напівпрілим. Відносна вологість гною становить 74-77 \% і залежить від витрат підстилки та терміну очищення корівника. Об'ємна маса гною в корівниках 3 глибокою підстилкою в непорушеній структурі гнойового шару перебуває в межах $0,95-0,98 \mathrm{~T} / \mathrm{M}^{3}$, насипна маса $-0,5-0,72 \mathrm{~T} / \mathrm{M}^{3}$.

На даний момент встановлено, що третина антропогенного забруднення атмосфери землі викликана виробництвом сільськогосподарської продукції. Тваринництво належить до основних ії забруднювачів. За прогнозом FAO, надалі становище може погіршитися, оскільки попит на білок тваринного походження в світі зростає. Сьогодні виробництво тваринницької продукції дає 9 \% світових викидів найпоширенішого парникового газу - вуглекислого, 65 \% закису азоту, більшість якого міститься у гної тварин, 37 \% всього антропогенного метану і $64 \%$ аміаку (FAO, 2017).

Серед пропозицій щодо захисту навколишнього середовища під час виробництва молока важлива роль відводиться вдосконаленню технологій утримання тварин - це одна 3 небагатьох конструктивних можливостей зменшити забруднення без радикальних заходів, пов'язаних з відмовою від виробництва цих продуктів (Borshch et al., 2020a; Borshch et al., 2021). У зв'язку 3 цим у більшості розвинених країн впроваджуються технології 3 кращими екологічними показниками.

Метою роботи було порівняння показників якості органічних добрив за різних способів зберігання гною та вивчення впливу способу зберігання гною на забруднення довкілля. 


\section{Матеріал і методи досліджень}

Дослідження проводили у трьох господарствах Київської області 3 різними способами видалення, зберігання та переробки гною: 3 використанням глибокої довгонезмінюваної солом'яної підстилки (видалення гною тричі на рік); з переробкою гною в біореакторі-ферментері закритого типу; $з$ відстоюванням гною у лагунах відкритого типу. У всіх господарствах середньорічне поголів'я становило 400 дійних корів.

Проби для аналізу гною (відходів переробки) відбирали за добу до вивезення в поле. Середня добова температура повітря становила $+21,3{ }^{\circ} \mathrm{C}$. Наявність сторонніх включень визначали шляхом відбору проб гною вагою 1 кг кожна в трьох місцях резервуара. 3 цих проб виділяли і зважували сторонні включення (каміння, металеві предмети та ін.).

Вміст органічної речовини встановлювали за методом визначення зольності. Висушену пробу масою 5,0-10,0 г поміщали в тиглі, які розміщували в муфельній печі та нагрівали до появи диму. Тривалість спалювання, яка залежить від хімічного складу гною, становила від 5 до 6 год. Світло-сірий колір золи і відсутність частинок вугілля вказує на повне озолення матеріалу. Вміст Фосфору визначали фотометричним методом, який грунтується на мінералізації сухої органічної речовини під час нагрівання 3 концентрованою сірчаною кислотою в присутності перекису водню 3 подальшим визначенням оптичної густини пофарбованого фосфорно-молібденового комплексу, відновленого до молібденової сині. Вміст Калію визначали вогнево-фотометричним методом. Метод грунтується на мінералізації сухої органічної речови- ни під час нагрівання 3 концентрованою сірчаною кислотою в присутності перекису водню чи змішаного каталізатора 3 подальшим визначенням загального Калію (GOST 26715-85; GOST 26717-85; GOST 26718-85).

Температуру гною визначали шляхом прямого вимірювання на глибині 40-45 см за допомогою термометра A36PF-D43 (США).

Викиди $\mathrm{N}_{2} \mathrm{O}$ (оксид азоту) та $\mathrm{N}$ в результаті прибирання, зберігання і використання гною та втрати $\mathrm{N}$ в результаті випаровування визначали за загальноприйнятими методиками (MGEIK, 2006).

Матеріали досліджень обробляли методом варіаційної статистики на основі розрахунку середнього арифметичного, середньоквадратичної похибки та достовірності різниці між порівнюваними показниками. Вірогідність отриманих результатів і різницю між показниками розраховували за $t$-критерієм Стьюдента. Для показу вірогідності в таблицях прийнято умовні позначення $\mathrm{P}>0,95 ; \mathrm{P}>0,99 ; \mathrm{P}>0,999$, які у статті відповідно позначені зірочками $\left({ }^{*} ; * ; * * *\right)$.

\section{Результати та їх обговорення}

Найбільш вагомими елементами, котрі містяться у складі органічних добрив є Азот, Фосфор і Калій та їні сполуки. Встановлено, що за сумою вмісту Азоту, Фосфору і Калію у 1 кг добрив найвищі показники спостерігали за варіанту утримання на глибокій підстилці - 7,69 г (табл. 1). Найменше цих елементів було у добриві, отриманому в результаті зберігання у лагуні - 6,16 г. За способу переробки гною у біореакторіферментері спостерігали проміжні показники - 6,69 г.

\section{Таблиця 1}

Вміст Азоту, Фосфору і Калію в органічному добриві залежно від варіантів видалення, зберігання та переробки гною, Г/кг

\begin{tabular}{lccc}
\hline \multirow{2}{*}{ Елемент } & \multicolumn{3}{c}{ Спосіб зберігання (переробки) гною (n=10) } \\
\cline { 2 - 4 } & Глибока довгонезмінювана підстилка & Біореактор-ферментер & Лагуна відкритого типу \\
\hline Азот & $3,16 \pm 0,08$ & $2,84 \pm 0,09^{*}$ & $2,63 \pm 0,08^{* * *}$ \\
Фосфор & $2,34 \pm 0,09$ & $2,01 \pm 0,06^{* *}$ & $1,87 \pm 0,06^{* * *}$ \\
Калій & $2,19 \pm 0,15$ & $1,84 \pm 0,14$ & $1,66 \pm 0,07^{* *}$ \\
\hline puмітка: ${ }^{*}-\mathrm{P} \geq 0,95 ;^{* *}-\mathrm{P} \geq 0,99 ;^{* * *}-\mathrm{P} \geq 0,999$ порівняно зі зберіганням на глибокій довгонезмінюваній підстилці
\end{tabular}

Встановлено, що найвищий показник вологості гною був за зберігання в лагуні - на $17,71 \%$ та $1,38 \%$ більше порівняно з варіантом на глибокій підстилці та в біореакторі-ферментері (табл. 2). Масова частка органічної речовини гною була найвищою за накопичення і зберігання гною у корівнику (глибока підстилка) $-81,72 \%$, а це на 4,44 та 7,66 \% більше, ніж за технологій з використанням біореактора-ферментера та лагуни відповідно. Таку ж ситуацію спостерігали і за вмістом найбільш необхідних для запобігання деградації (ерозії) грунтів макроелементів - Азотом, Фосфором та Калієм. За способу переробки гною в біореакторі-ферментері спостерігали найнижчий показник сторонніх включень - 0,014 \%, що на 0,013 та 0,008 \% менше, ніж за переробки у глибокій підстилці та в лагуні. Найменша кількість насіння бур'янів була за зберігання на глибокій підстилці - 84 шт/мл, що на 19 та 23 шт/мл менше, ніж за переробки у біореакторіферментері та в лагуні відповідно. Це пояснюється тим, що в процесі ферментації у глибокій підстилці, котрий триває упродовж 3,5 місяця (110 діб), частина насіння бур'янів та соломи перепріває та рокладається. Показник схожості бур'янів, котрий є дуже важливим 3 точки зору майбутнього використання гною як добрива, був дещо нижчим за зберігання на глибокій підстилці і становив 5,72\%, за переробки у біореакторіферментері цей показник становив 8,86 \%, а в лагуні $10,14 \%$. Температура зберігання гною у лагуні була на нижчою на 5,56 та $3,74{ }^{\circ} \mathrm{C}$ порівняно зі зберіганням на глибокій підстилці та у біореакторі-ферментері. 
Таблиця 2

Показники якості органічного добрива залежно від способу зберігання гною

\begin{tabular}{|c|c|c|c|}
\hline \multirow[b]{2}{*}{ Показник } & \multicolumn{3}{|c|}{ Спосіб зберігання (переробки) гною (n = 10) } \\
\hline & $\begin{array}{c}\text { Глибока довгонезмінювана } \\
\text { підстилка } \\
\end{array}$ & Біореактор-ферментер & $\begin{array}{c}\text { Лагуна відкритого } \\
\text { типу } \\
\end{array}$ \\
\hline Вологість, \% & $75,54 \pm 1,37$ & $93,87 \pm 1,86^{* * *}$ & $95,25 \pm 2,08^{* * *}$ \\
\hline Масова частка органічної речовини, \% & $81,72 \pm 2,81$ & $77,28 \pm 2,53$ & $74,06 \pm 2,64$ \\
\hline Наявність сторонніх включень, \% & $0,027 \pm 0,0084$ & $0,014 \pm 0,0036$ & $0,022 \pm 0,059$ \\
\hline Наявність насіння бур'янів, шт/мл & $84 \pm 2,83$ & $103 \pm 3,18^{* * *}$ & $107 \pm 3,53^{* * *}$ \\
\hline Схожість насіння бур'янів, \% & $5,72 \pm 0,73$ & $8,86 \pm 1,16^{*}$ & $10,14 \pm 1,36^{*}$ \\
\hline Температура, ${ }^{\circ} \mathrm{C}$ & $44,07 \pm 0,94$ & $42,31 \pm 0,46$ & $38,57 \pm 0,59^{* * *}$ \\
\hline
\end{tabular}

Примітка: ${ }^{*}-\mathrm{P} \geq 0,95 ;^{* * *}-\mathrm{P} \geq 0,999$ порівняно зі зберіганням на глибокій довгонезмінюваній підстилці

Інтенсифікація сільського господарства загалом і тваринництва зокрема є фактором збільшення викидів вуглекислого газу, метану, аміаку, оксиду азоту, летких речовин та інших газів у атмосферу, що своєю чергою руйнує озоновий шар та впливає на глобальні процеси зміни клімату в світі. Американські вчені встановили, що одна корова ентерально та в складі екскрементів виділяє від 250 до 500 літрів метану щодоби. Цей процес залежить не тільки від структури раціону та концентрації у ньому концентрованих i соковитих кормів, а й від технологій утримання тва- рин та способів видалення, зберігання і експлуатації гною на фермах (Tien et al., 2017).

Найбільші викиди $\mathrm{N}_{2} \mathrm{O}$, котрий $є$ озоноруйнуючою речовиною, а також парниковим газом, були за способу зберігання гною у відкритій лагуні - 40712,45 кг (табл. 3). За зберігання у глибокій підстилці та в біореакторі-ферментері цей показник становив 930,57 кг. Така ж ситуація спостерігалась і 3 викидами $\mathrm{N}_{2} \mathrm{O}$ в результаті випаровування - 56997,43 кг за зберігання у відкритій лагуні, проти 3722,28 кг та 3256,99 кг за зберігання на глибокій підстилці та у біореакторіферментері відповідно.

Таблиця 3

Вплив способу зберігання гною на забруднення довкілля

\begin{tabular}{lccc}
\hline \multirow{2}{*}{ Показник } & \multicolumn{2}{c}{ Спосіб зберігання (переробки) гною (n=400) } \\
\cline { 2 - 4 } & $\begin{array}{c}\text { Глибока довгонезмінювана } \\
\text { підстилка }\end{array}$ & $\begin{array}{c}\text { Біореактор- } \\
\text { ферментер }\end{array}$ & $\begin{array}{c}\text { Лагуна відкритого } \\
\text { типу }\end{array}$ \\
\hline $\begin{array}{l}\text { Викиди } \mathrm{N}_{2} \mathrm{O} \text { в результаті прибирання, } \\
\text { зберігання і переробки гною, кг/рік }\end{array}$ & 930,57 & 930,57 & 40712,45 \\
$\begin{array}{l}\text { Викиди } \mathrm{N}_{2} \mathrm{O} \text { в результаті випаровування, } \\
\text { кг/рік }\end{array}$ & 3722,28 & 3256,99 & 56997,43 \\
$\begin{array}{l}\text { Втрати N в результаті прибирання, } \\
\text { зберігання і переробки гною, кг/рік } \\
\text { Втрати N в результаті випаровування, кг/рік }\end{array}$ & 5927,20 & 2963,60 & 51863,01 \\
\hline
\end{tabular}

Втрати N, котрий за великих концентрацій у повітрі може викликати у тварин задуху, також були найвищими за способу зберігання гною у лагуні 51863,01 кг в результаті прибирання, зберігання i переробки гною та 181520,50 кг в результаті випаровування. Значно більші викиди $\mathrm{N}_{2} \mathrm{O}$ та $\mathrm{N}$ за умов зберігання гною у лагуні відкритого типу пояснюються суттєво вищими значеннями показників частки річного виділення $\mathrm{N}$ та коефіцієнта викидів $\mathrm{N}_{2} \mathrm{O}$, порівняно зі зберіганням у глибокій підстилці та в анаеробному біореакторі-ферментері.

\section{Висновки}

Встановлено, що спосіб видалення, зберігання i переробки гною впливає на показники якості отриманого 3 нього органічного добрива та кількість викидів в атмосферу $\mathrm{N}_{2} \mathrm{O}$ i втрат N. За способу видалення i зберігання гною на глибокій солом'яній підстилці його якісні та санітарні показники були кращими i безпечнішими, ніж за варіантів переробки у закритому біореакторі-ферментері та в лагуні. Найнижчі по- казники викидів $\mathrm{N}_{2} \mathrm{O}$ та втрат $\mathrm{N}$ були за переробки гною у біореакторі-ферментері. При цьому вміст Азоту, Фосфору, Калію та органічної речовини добрива, отриманого з глибокої підстилки, переважав аналогічні показники добрива, отриманого за інших способів зберігання за рахунок щоденного внесення соломи. До того ж така система видалення, зберігання і переробки гною потребує значно менших капітальних витрат порівняно 3 переробкою у біореакторіферментері та зберіганням у лагунах.

Відомості про конфлікт інтересів. Автори стверджують про відсутність конфлікту інтересів щодо іхнього вкладу та результатів досліджень.

\section{References}

Amon, T., Amon B., Kryvoruchko, V., Zollitsch, W., Mayer, K., \& Gruber, L. (2007). Biogas production from maize and dairy cattle manure-Influence of biomass composition on the methane yield. Agriculture, 
Ecosystems and Environment, 118, 173-182. doi: 10.1016/j.agee.2006.05.007.

Barret, M., Gagnon, N., Topp, E., Masse, L., Massé, D. I., \& Talbot, G. (2013). Physico-chemical characteristics and methanogen communities in swine and dairy manure storage tanks: Spatio-temporal variations and impact on methanogenic activity. Water Research, 47(2), 26-40. doi: 10.1016/j.watres.2012.10.047.

Borshch, O. O., Borshch, O. V., Donchenko, T. A., Kosior, L. T., \& Pirova, L. V. (2017). Influence of low temperatures on behavior, productivity and bioenergy parameters of dairy cows kept in cubicle stalls and deep litter system. Ukrainian Journal of Ecology, 7(3), 73-77. doi: 10.15421/2017 51.

Borshch, O. O., Ruban, S. Yu., Gutyj, B. V., Borshch, O. V., Sobolev, O. I., Kosior, L. T., Fedorchenko, M. M., Kirii, A. A., Pivtorak, Y. I., Salamakha, I. Yu., Hordiichuk, N. M., Hordiichuk, L. M., Kamratska, O. I., Denkovich, B. S. (2020a). Comfort and cow behavior during periods of intense precipitation. Ukrainian Journal of Ecology, 10(6), 98-102. doi: 10.15421/2020_265.

Borshch, O. O., Gutyj, B. V., Borshch, O. V., Sobolev, O. I., Chernyuk, S. V., Rudenko, O. P., Kalyn, B. M., Lytvyn, N. A., Savchuk, L. B., Kit, L. P., Nahirniak, T. B., Kropyvka, S. I., \& Pundyak, T. O. (2020b). Environmental pollution caused by the manure storage. Ukrainian Journal of Ecology, 10(3), 110 114. doi: 10.15421/2020_142.

Borshch, O. O., Borshch, O. V., Sobolev, O. I., Nadtochii, V. M., Slusar, M. V., Gutyj, B. V., Polishchuk, S. A., Malina, V. V., Korol, A. P., Korol-Bezpala, L. P., Bezpalyi, I. F., \& Cherniavskyi, O. O. (2021). Wind speed in easily assembled premises with different design constructions for side curtains in winter. Ukrainian Journal of Ecology, 11(1), 325-328. doi: $10.15421 / 2021449$.

Cao, X., \& Harris, W. (2010). Properties of dairy-manurederived biochar pertinent to its potential use in remediation. Bioresourse Technology, 101(14), 5222 5228. doi: 10.1016/j.biortech.2010.02.052.

Coats, E. R., Gregg, M., \& Crawford, R. L. (2011). Effect of organic loading and retention time on dairy manure fermentation. Bioresourse Technology, 102(3), 25722577. doi: 10.1016/j.biortech.2010.11.108.

Coats, E. R., Watson, B. S., \& Brinkman, C. K. (2016). Polyhydroxyalkanoate Synthesis by Mixed Microbial Consortia Cultured on Fermented Dairy Manure: Effect of Aeration on Process Rates/Yields and the Associated Microbial Ecology. Water Research, 106, 26-40. doi: 10.1016/j.watres.2016.09.039.

Food and Agriculture Organization of the United Nations (FAO). The Impact of Disasters on Agriculture Assessing the information gap, available at: http://www.fao.org/3/a-i7279e.pdf (last access: 21 December 2020), 2017.

GOST 26715-85. Udobreniya organicheskie. Metodyi opredeleniya obschego azota. Vved. 1987-01-01. M.: Gosudarstvennyiy komitet SSSR po standartam, 1986. 12 s (in Russian).

GOST 26717-85. Udobreniya organicheskie. Metodyi opredeleniya obschego fosfora. Vved. 1987-01-01.-
M.: Gosudarstvennyiy komitet SSSR po standartam, 1986. $6 \mathrm{~s}$ (in Russian).

GOST 26718-85. Udobreniya organicheskie. Metodyi opredeleniya obschego kaliya. Vved. 1987-01-01. M.: Gosudarstvennyiy komitet SSSR po standartam, 1986. $4 \mathrm{~s}$ (in Russian).

Hanson, A. J., Guho, N. M., Paszczynski, A. J., \& Coats, E. R. (2016). Community proteomics provides functional insight into polyhydroxyalkanoate production by a mixed microbial culture cultivated on fermented dairy manure. Applied Biochemistry and Biotechnology, 100(18), 7957-7976. doi: 10.1007/s00253-016-7576-7.

Hoffmann, R. A., Garcia, M. L., Veskivar, M., Karim, K., Al-Dahhan, M. H., \& Angenent, L. T. (2007). Effect of Shear on Performance and Microbial Ecology of Continuously Stirred Anaerobic Digesters Treating Animal Manure. Biotechnology and Bioengineering, 100, 38-48. doi: 10.1002/BIT.21730.

Janzen, R. A., McGill, W. B., Leonard, J. J., \& Jeffrey, S. R. (1999). Manure as a resource-ecological and economic considerations in balance. Transactions of the ASAE, 42(5), 1261-1274. doi: 10.13031/2013.13291.

Resende, J. A., Silva, V. L., Rocha de Oliveira, T. M., Fortunato, S. O., Carneiro, J. C., Otenio, M. H., \& Diniz, C. G. (2014). Prevalence and persistence of potentially pathogenic and antibiotic resistant bacteria during anaerobic digestion treatment of cattle manure. Bioresourse Technology, (153), 284-291. doi: 10.1016/j.biortech.2013.12.007.

Ruban, S. Yu., Borshch, O. V., \& Borshch, O. O. (2017). Suchasni tekhnolohiyi vyrobnytstva moloka. (osoblyvosti ekspluatatsiyi, tekhnolohichni rishennya, eskizni proekty) [Modern milk production technologies. (Peculiarities of operation, technological decisions, sketch designs)]. Kharkiv: STYLIZDAT (in Ukrainian).

Ruban, S., Borshch, O. O., Borshch, O. V., Orischuk, O., Balatskiy, Y., Fedorchenko, M., Kachan, A., \& Zlochevskiy, M. (2020). The impact of high temperatures on respiration rate, breathing condition and productivity of dairy cows in different production systems. Animal Science Papers and Reports, 38(1), 61-72.

Rukovodyaschie printsipyi natsionalnyih inventarizatsiy parnikovyih gazov MGEIK, 2006. 73 s (in Russian).

Stowe, E. J., Coats, E. R., \& Brinkman, C. K. (2015). Dairy manure resource recovery utilizing two-stage anaerobic digestion - implications of solids fractionation. Bioresourse Technology, 198, 237-245. doi: 10.1016/j.biortech.2015.09.017.

Tien, Y. C., Li, B., Zhang, T., Scott, A., Murray, R., Sabourin, L., Marti, R., \& Topp, E. (2017). Impact of dairy manure pre-application treatment on manure composition, soil dynamics of antibiotic resistance genes, and abundance of antibiotic-resistance genes on vegetables at harvest. Science of The Total Environment, 581582(1), 32-39. doi: 10.1016/j.scitotenv.2016.12.138.

Toumi, J., Miladi, B., Farhat, A., Nouira, S., Hamdi, M., Gtari, M., \& Bouallagu, H. (2015). Microbial ecology overview during anaerobic codigestion of dairy wastewater and cattle manure and use in agriculture of obtained bio-fertilisers. Bioresourse Technology, 198, 141-149. doi: 10.1016/j.biortech.2015.09.004. 
Walsh, J. J., Rousk, J., Edwards-Jones, G., Jones, D. L., \& Williams, A. P. (2012). Fungal and bacterial growth following the application of slurry and anaerobic digestate of livestock manure to temperate pasture soils. Biology and Fertility of Soils, 48, 889-897.

Wang, X., Yang, G., Feng, Y., Ren, G., \& Han, X. (2012). Optimizing feeding composition and carbonnitrogen ratios for improved methane yield during an- aerobic co-digestion of dairy, chicken manure and wheat straw. Bioresourse Technology, 120, 78-83. doi: 10.1016/j.biortech.2012.06.058.

Zhong, W., Gu, T., Wang, W., Zhang, B., Lin, X., Huang, Q., \& Shen, W. (2012). The effect of mineral fertilizer and organic manure on soil microbial community and diversity. Plant and Soil, 326(1-2), 511-522. doi: 10.1007/s11104-009-9988-y. 